\title{
Recent Advances in the Use of Transglutaminase in Cheese Production
}

\author{
Warsono El Kiyat ${ }^{1, *}$, Evlyn Laurenthia ${ }^{2}$, Janice Michaela ${ }^{2}$, and Rizi Fariz Pari ${ }^{3}$ \\ ${ }^{1}$ Department of Food Science, College of Food and Agriculture, United Arab Emirates University, Sheik Khalifa Bin Zayed Street, 'Asharij, \\ Al Ain, Abu Dhabi 15551, United Arab Emirates \\ ${ }^{2}$ Department of Food Technology, Faculty of Life Sciences, Universitas Surya, Grand Serpong Mall F8 and F9, Jl. MH. Thamrin, North \\ Panunggangan, Pinang, Tangerang, Banten 15143, Indonesia \\ ${ }^{3}$ Department of Aquatic Product Technology, Faculty of Fisheries and Marine Sciences, IPB University, Jl. Agatis, Babakan, Dramaga, \\ Bogor 16680, Indonesia \\ *Corresponding author: warsono.el.kiyat@gmail.com
}

\section{KEYWORDS \\ Casein \\ Cheese \\ Crosslinking \\ Enzyme \\ Milk}

SUBMITTED 21 February 2021

REVISED 23 August 2021

ACCEPTED 26 August 2021

\begin{abstract}
Various enzymes are used in the food industry to improve product quality. The enzyme transglutaminase is used to modify proteins in various foods through the formation of inter- and intramolecular $\epsilon$-( $\gamma$-glutamyl) lysine bonds. Previous studies have revealed that using transglutaminase in cheese production can increase the yield and enhance the characteristics of various types of cheese. However, the enzyme concentration, temperature, and pH influence the quality of cheese. This review aimed to discuss the potential of transglutaminase in cheese production. Our analysis showed that transglutaminase catalyzes the formation of covalent bonds between milk proteins (crosslinking), which results in a greater amount of casein trapped from whey and a higher yield of curd. Transglutaminase can also reduce production costs without negatively affecting cheese quality. These findings should prove useful in developing cheese products to improve consumer satisfaction.
\end{abstract}

(c) The Author(s) 2021. This article is distributed under a Creative Commons Attribution-ShareAlike 4.0 International license.

\section{INTRODUCTION}

Milk is a nutrient-rich food. Other than the dairy cow, milk for human consumption is obtained from the water buffalo, goat, and sheep. The main components of milk are water, lactose, lipids, proteins, and minerals. The main food products produced from milk include cheese, yogurt, and kefir.

Cheese is an excellent source of calcium and is useful in maintaining healthy bones and teeth. Cheese is produced by separating milk into solid curds and liquid whey by coagulation (Afandi et al. 2013). During cheese production, casein, the main milk protein, is coagulated using proteolytic enzymes. Rennet, one of the most commonly used enzymes in cheese production, comprises a mixture of enzymes and is produced in the stomach of ruminant mammals. Chymosin is the key component of rennet that curdles milk casein, which then becomes insoluble in water and allows it to separate from the solution (Miskiyah et al. 2011; Ozcan and Eren-Vapur 2013).

Cheese is a relatively recent import to Indonesia and is often combined with various other food products. Cheese consumption in Indonesia continues to increase and was approximately 19,000 tons in 2013 (Ozcan and Eren-Vapur 2013). However, cheese production in Indonesia is insufficient at fulfilling consumer demand; therefore, cheese is often imported. The import of cheese has continued to increase by $5 \%$ annually (Rangkuti and Wright 2015). The retail value of cheese in Indonesia is estimated to increase $12 \%$ annually (Ouyang et al. 2021). Imported cheeses in Indonesia are regulated to make sure that the content is suitable for all Indonesian people (Ministry of Trade of the
Republic of Indonesia 2019; United States Department of Agriculture Foreign Agricultural Service 2019). This has resulted in an increase in its price, and consequently more effective production methods are needed to fulfill consumer demand while simultaneously controlling costs and increasing profits.

Various enzymes are employed in the food industry to improve the texture, flavor, nutritional value, and production efficiency of products. Transglutaminase is one of the enzymes used in the cheese production industry. This enzyme improves the yield and water-holding capacity of cheese and enhances its soft texture (Romeih and Walker 2017). The focus of this review article is the use of transglutaminase to improve the efficiency of cheese production.

\section{CHARACTERISTICS OF TRANSGLUTAMINASE}

Transglutaminase (EC 2.3.2.13 protein-glutamine gammaglutamyltransferase; Sidauruk et al. 2017; United States Department of Agriculture 2017) is an enzyme that catalyzes the formation covalent bonds between lysine and glutamic acid residues (Fawzya 2016), and can improve food products' physical properties (Kieliszek and Misiewicz 2014), flavor, and appearance (Zilda 2014). In addition, this enzyme has gelling capabilities (Chasanah and Fawzya 2014), and can stabilize proteins for improved digestibility (Monogioudi et al. 2011), as well as prevent allergies (Martins et al. 2014). Transglutaminase is used to crosslink proteins during various food production processes (Buettner et al. 2011; Campos et al. 2013; Giosafatto et al. 2012). The catalytic mechanism of transglutaminase is shown in Figure 1. 
Transglutaminase is widely distributed in nature and is produced by animals, plants, and microorganisms Shleikin et al. (2011); de Góes-Favoni and Bueno (2014). Transglutaminase was first found in animal tissues and lungs with expensive production and was unacceptable for some people (Sorapukdee and Tangwatcharin 2018). Transglutaminase is also found in plants, although it is hard to extract and purify (Duarte et al. 2020). Microbial transglutaminase has been widely developed for industrial applications, because it is cheaper and simpler to generate and purify (Muhammad et al. 2021). This enzyme works optimally at a pH of 58 , but still shows enzymatic activities at a pH of 4 or 9 with a specific activity of $22.6 \mathrm{U} / \mathrm{mg}$ (Motoki and Seguro 1998). Moreover, transglutaminase is active and stable between pH 5 and 9, which is the range at which most food products are processed (Martins et al. 2014)). The enzymatic activity of transglutaminase is optimum at a temperature range of $50-55^{\circ} \mathrm{C}$, and the enzyme shows continuous activity at $50^{\circ} \mathrm{C}$ for $10 \mathrm{~min}$. Transglutaminase can even work at temperatures as low as $10^{\circ} \mathrm{C}$, and some enzymatic activities are retained even at temperatures above freezing (Motoki and Seguro 1998). A previous study reported that the optimal temperature of transglutaminase activity is 45$50^{\circ} \mathrm{C}$ (Özer et al. 2013). However, the reaction rate seems to vary at lower temperatures. For example, transglutaminase isolated from Congresox talabon showed optimal substrate catalysis at $50^{\circ} \mathrm{C}$ and a pH of 7.5. In skimmed and reconstituted milk, transglutaminase has an optimal $\mathrm{pH}$ of 7.0-7.5 (Hinz et al. 2012). At pH 6.6, the enzymatic reaction begins earlier in the process (Bönisch et al. 2007). Activation of transglutaminase depends on the availability of metal ions (Sidauruk et al. 2017). The presence of divalent cations (i.e., $\mathrm{Cu}^{2+}, \mathrm{Zn}^{2+}, \mathrm{Pb}^{2+}, \mathrm{Li}^{2+}$, and $\mathrm{Mg}^{2+}$ ) inhibits enzyme activity, and the activity and thermal stability of the enzyme are increased in the presence of monovalent ions, such as $\mathrm{Na}^{+}$ and $\mathrm{K}^{+}$(Macedo 2009; Kütemeyer et al. 2005). In addition, because most proteins are unstable at low temperatures (Ali et al. 2010), the catalytic activity of transglutaminase varies with $\mathrm{pH}$ and temperature (Shi et al. 2011).

\section{APPLICATION OF TRANSGLUTAMINASE IN CHEESE PRODUCTION}

\subsection{White-brined cheese}

Transglutaminase effectively modifies the matrix of whitebrined cheese by crosslinking proteins to enhance the texture and yield and lower the total amount of solids compared with cheese made without using transglutaminase (control). Transglutaminase also increases the water retention potential by forming a gel via $\beta$-( $\alpha$-glutamyl) lysine residue linkages. The temperature at which renneting oc-

$$
\begin{aligned}
& \text { (a) } 1
\end{aligned}
$$

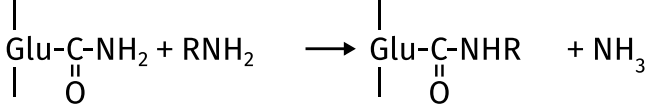

$$
\begin{aligned}
& \text { (b) } \\
& \underset{\mathrm{O}}{\mathrm{Glu}-\mathrm{C}-\mathrm{NH}_{2}}+\mathrm{H}_{2} \mathrm{~N} \text {-Lys } \rightarrow \underset{\mathrm{Glu}-\mathrm{C}-\mathrm{NH}-\text { Lys }}{\mid}+\mathrm{NH}_{3} \\
& \text { (c) } \\
& \underset{\mathrm{O}}{\mathrm{Glu}-\mathrm{C}-\mathrm{NH}_{2}}+\mathrm{H}_{2} \mathrm{O} \rightarrow \underset{\mathrm{O}}{\mathrm{Glu}-\mathrm{C}-\mathrm{OH}}+\mathrm{NH}_{3}
\end{aligned}
$$

FIGURE 1. Catalytic mechanism of transglutaminase. (a) Acyl transfer, (b) crosslinking of glutamine and lysine residues, (c) deamidation. curs directly affects the total amount of solids in the cheese. At a lower temperature $\left(30^{\circ} \mathrm{C}\right)$, the total amount of solids is higher in cheese made using transglutaminase compared with that in the control. Additionally, the water-binding capacity increases due to the higher level of protein polymerization of the rennet gel (Özer et al. 2013). According to Yüksel et al. (2011), transglutaminase should be added 5 min before adding rennet because of the kinetic reaction that is involved. The type of microbial transglutaminase used and the timing of the addition and temperature determine the water retention in the cheese. The addition of transglutaminase at $2.0 \mathrm{U} / \mathrm{g}$ with an incubation time of $18 \mathrm{~h}$ at $4^{\circ} \mathrm{C}$ increases the porosity of pork products from $42.0 \%$ to $45.6 \%$ (Prakasan et al. 2015). Meanwhile, heating transglutaminase-enhanced skim milk to $40^{\circ} \mathrm{C}$ or $50^{\circ} \mathrm{C}$ for 20-60 min increases the rate of protein polymerization and cheese yield (Mazuknaite et al. 2013).

At higher coagulation temperatures, the enzymatic rate of protein polymerization is increased, resulting in a higher yield. Adding transglutaminase induces a shift in the physical characteristics of casein gel, such as smaller pore sizes and greater retention of serum in the gel (Pierro et al. 2010). Compared with the control, transglutaminase increases protein content and produces cheese with a harder texture, but the hardness decreases when the coagulation process is conducted at $34^{\circ} \mathrm{C}$ (Table 1; Özer et al. 2013).

\subsection{Low-fat Iranian white cheese}

Low-fat Iranian white cheese is a brined cheese produced from cow's milk without drying the curd before salting (Figure 2; Sayadi et al. 2013). In comparison with the control, transglutaminase increases its yield, protein content, and hardness. A study of two cheese formulations revealed that adding transglutaminase and rennet increased the yield of low-fat cheese compared with the control $(9.2 \pm 0.28 \%$ vs. $6.5 \pm 0.45 \%$; Sayadi et al. 2013). The yield was enhanced by increasing the serum bonding of proteins within the gel tissue, which is strengthened through the formation of chemical bonds and the presence of casein in the tissue.

TABLE 1. Cheese yield under different treatment conditions, based on Özer et al. (2013).

\begin{tabular}{lcc}
\hline Cheese Treatment & Temperature $\left({ }^{\circ} \mathrm{C}\right)$ & Cheese yield (\%) \\
\hline Rennet & 34 & 17.93 \\
Rennet + Transglutaminase & 34 & 22.35 \\
Rennet & 30 & 15.33 \\
Rennet + Transglutaminase & 30 & 18.97 \\
\hline
\end{tabular}

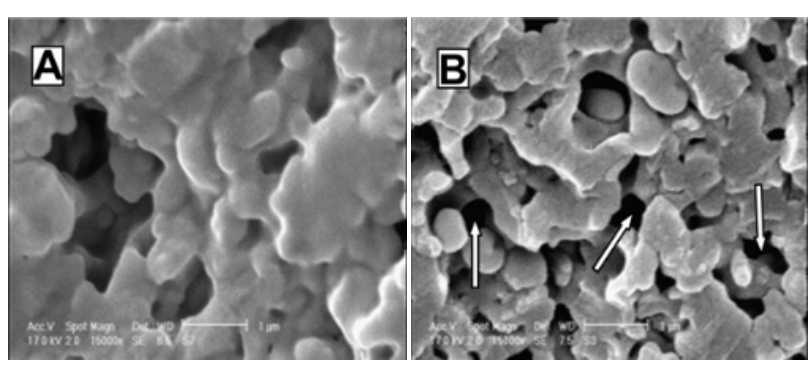

(a)

(b)

FIGURE 2. Transmission electron micrographs of Iranian white cheese. (a) Transglutaminase improved the cheese texture by increasing the moisture-to-protein ratio, (b) which was more pronounced with the addition of transglutaminase and rennet (Sayadi et al. 2013). 
TABLE 2. The composition, protein recovery, yield, and uniaxial compression parameters of cheese samples.

\begin{tabular}{lccc}
\hline Parameter & \multicolumn{3}{c}{ Cheese samples } \\
\cline { 2 - 4 } & $\mathrm{C}-\mathrm{C}$ & TG-C & WPI + TG-C \\
\hline Moisture (\%) & 55.83 & 58.71 & 61.06 \\
Protein (\%) & 31.74 & 27.59 & 29.41 \\
Fat (\%) & 4.12 & 4.24 & 3.58 \\
Yield (\%) & 6.5 & 9.2 & 9.7 \\
Protein recovery (\%) & 63.48 & 78.1 & 80.35 \\
Mositure:protein ratio & 1.75 & 2.12 & 2.07 \\
Stress at fracture (kPa) & 189.6 & 123 & 164.3 \\
Young's modulus (kPa) & 983 & 346 & 610 \\
\hline
\end{tabular}

Abbreviations: C-C, low-fat cheese; TG-C, low-fat cheese with transglutaminase; WPI + TG-C, low-fat cheese supplemented with whey protein isolates and transglutaminase (Sayadi et al. 2013).

\subsection{Edam cheese}

Edam cheese is a semi-hard variety of cheese (Darnay et al. 2017) and was the most popular cheese in the world between the 14th and 18th centuries (Edam, Cheese and the City 2005). Edam cheese is one of the most exported cheeses from the Netherlands and accounted for approximately $60 \%$ of all the cheese produced in Portugal in 2002 (Oliveira et al. 2011).

Bönisch et al. (2008) reported that transglutaminase can increase the yield, improve the texture, and produce gels in cheese products without adding other chemicals. However, transglutaminase is generally not used in the production of semi-hard and hard cheeses due to some negative effects of the enzyme, such as poor coagulation, increased coagulation time, and decreased gel-formation properties of the milk. Aaltonen et al. (2014) reported that transglutaminase significantly increased the yield of cheese by binding additional water molecules without reducing the hardness of the cheese due to the crosslinking of protein molecules. Therefore, using transglutaminase can reduce production costs without sacrificing quality. In addition, the enzyme also reduces the ripeness progression.

\section{CHEMICAL PROPERTIES AND CHEESE RHEOLOGY WITH THE ADDITION OF TRANSGLUTAMINASE}

The addition of microbial transglutaminase was reported to increase the moisture content in various cheeses, including white-brined cheese (Özer et al. 2013), low-fat cheddar cheese (Hu et al. 2013), low-fat Iranian white cheese (Sayadi et al. 2012, 2013), Edam cheese (Aaltonen et al. 2014), panela cheese (Salinas-Valdés et al. 2015), Italian and Polish crosslinked cheeses (Domagała et al. 2015), and ultrafiltration (UF)-white soft cheeses (Ibrahim et al. 2016).

Pierro et al. (2010) reported changes in the chemical composition and rheology of cheeses with and without the addition of transglutaminase isolated from Streptoverticillium mobaraensis. The yield of cheese produced from 2.5 $\mathrm{L}$ of milk was lesser in the control sample (C1) than with transglutaminase $(\mathrm{C} 2 ; 11.76 \pm 1.01 \%$ vs. $14.82 \pm 1.15 \%)$. In addition, the protein content in the modified (crosslinked) cheese was significantly higher than the control. According to Ibrahim et al. (2016), the crosslinking reaction catalyzed by transglutaminase improves the texture, as well as the nutritional properties, essential amino acid content, and protein efficiency ratio of the cheese.
TABLE 3. Comparison of the syneresis values of cheeses with and without the addition of transglutaminase (Pierro et al. 2010).

\begin{tabular}{lcc}
\hline Syneresis determination method & Control & With transglutaminase \\
\hline Drainage method & $374 \pm 20$ & $215 \pm 20$ \\
One hour syneresis & $124 \pm 12$ & $38 \pm 5$ \\
\hline
\end{tabular}

A study by Sayadi et al. (2013) of the crosslinking of whey proteins in Iranian white cheese showed that transglutaminase increases the moisture-to-protein ratio of lowfat cheese, resulting in a significant reduction in fracture stress, Young's modulus, and storage modulus. Adding whey protein isolates to casein-enriched milk resulted in greater protein recovery than when using transglutaminase alone (Table 2).

The addition of transglutaminase was also reported to enhance the hardness of panela-type (Jimenez 2013), mozzarella (Sarghini et al. 2013), UF Iranian white (Hoseyni Aghdam et al. 2013), white-brined (Özer et al. 2013), low-fat gouda-like (Ahmed et al. 2016), paneer (Prakasan et al. 2015), and goat's whey (Mahmood et al. 2016) cheeses. Moreover, the addition of transglutaminase at a concentration of $5 \mathrm{U} / \mathrm{g}$ protein reportedly caused significant changes $(p$ $\leq 0.05$ ) in the body and texture of UF-white soft cheese after storing for 7-30 days (Ibrahim et al. 2016). Domagała et al. (2015) found that the coagulation time was affected by transglutaminase and gel texture. The longest rennet coagulation time ( $>91 \%$ vs. control) and the lowest gel firmness ( $<38 \%$ vs. control) was observed at the highest concentration of transglutaminase $(3 \mathrm{U} / \mathrm{g})$ with incubation at $40^{\circ} \mathrm{C}$ for $2 \mathrm{~h}$. Furthermore, transglutaminase lowered the syneresis of cheese (Table 3). According to Pierro et al. (2010), transglutaminase can modify the structure of paracasein, which influences the proteolytic pattern and texture quality of dairy products.

\section{PATENTS FOR CHEESE PRODUCTION WITH THE ADDITION OF TRANSGLUTAMINASE}

Transglutaminase has been widely applied in various foods, cosmetics, and many other types of products (e.g., Kuraishi et al. 1997), due to its crosslinking characteristics and ability to catalyze protein transamidation. At present, there are thousands of patents for the use of transglutaminase. Table 4 presents the patents that involve the use of transglutaminase to increase the yield in cheese production and improve product quality.

According to Kumazawa and Miwa (2009), transglutaminase increases the yield of cheese curd via two different processes. The first process involves the addition of transglutaminase into raw milk after adding the coagulation enzyme at low temperatures and then increasing the temperature to proceed with the coagulation process. The second process involves the addition of transglutaminase to raw milk at low temperatures, then increasing the temperature until coagulation proceeds successfully.

It is important to improve the shelf-life of cheese to maintain freshness. Enhancing the sensory quality of cheese is also critical to improve market demand. Preferences in the sensory quality of cheeses may differ from countries in other regions, which depends on the familiarity of people to the cheese type in that particular market (Ojeda et al. 2021). East Asian consumers prefer soft cheeses with a mild and milky texture (Ouyang et al. 2021), 
TABLE 4. Patents involving the use of transglutaminase in cheese production.

\begin{tabular}{|c|c|c|c|}
\hline Patent no. & Title & Product application & Inventor, country \\
\hline US5681598 & $\begin{array}{l}\text { "Process for producing cheese using } \\
\text { transglutaminase" }\end{array}$ & Fresh cheese production. & Kuraishi et al. (1997), Japan \\
\hline US5866180 & $\begin{array}{l}\text { "Method for production of an acidified edible } \\
\text { gel on milk basis" }\end{array}$ & $\begin{array}{l}\text { Production of milk curd with additional acid } \\
\text { in the production of yogurt and cheese. }\end{array}$ & $\begin{array}{l}\text { Budolfsen and Nielsen (1999), } \\
\text { Denmark }\end{array}$ \\
\hline US6093424 & $\begin{array}{l}\text { "Process for making cheese using } \\
\text { transglutaminase and a non-rennet protease" }\end{array}$ & $\begin{array}{l}\text { Production of large amounts of cheese curd } \\
\text { containing whey protein. }\end{array}$ & Han and Spradlin (2000), USA \\
\hline US6258390 B1 & "Process for making cheese" & $\begin{array}{l}\text { Production of conventional cheese with } \\
\text { transglutaminase. }\end{array}$ & Budtz (2001), Denmark \\
\hline US6224914 B1 & $\begin{array}{l}\text { "Process for incorporating whey proteins into } \\
\text { cheese using transglutaminase" }\end{array}$ & $\begin{array}{l}\text { Cheese production from milk enhanced with } \\
\text { whey protein, transglutaminase, and rennet. }\end{array}$ & Han and Spradlin (2001), USA \\
\hline US6572901 B2 & $\begin{array}{l}\text { "Process for making a cheese product using } \\
\text { transglutaminase" }\end{array}$ & $\begin{array}{l}\text { Development of a coagulation process for } \\
\text { soft cheese types with acid addition. }\end{array}$ & Han et al. (2003), USA \\
\hline US6749873 B2 & "Cheese yield enhancing Method" & $\begin{array}{l}\text { Cheese produced from milk containing whey } \\
\text { protein and transglutaminase hydrolyzates. }\end{array}$ & Kumazawa et al. (2004), Japan \\
\hline US7108876 B2 & $\begin{array}{l}\text { "Shaped cheese reconstruction with } \\
\text { transglutaminase" }\end{array}$ & $\begin{array}{l}\text { Development and quality of recombinant } \\
\text { curd. }\end{array}$ & $\begin{array}{l}\text { Grindstaff and Chappell (2006), } \\
\text { USA }\end{array}$ \\
\hline US7504119 B2 & "Process for producing cheese curd" & Production of cheese curd. & $\begin{array}{l}\text { Kumazawa and Miwa (2009), } \\
\text { Japan }\end{array}$ \\
\hline
\end{tabular}

which can be obtained by adding $60 \mathrm{U} / \mathrm{L}$ of transglutaminase after coagulation and curd cutting (Mahmood 2009). In addition, cheese products should be more widely distributed to intensify cheese consumption and expand the market in Indonesia.

\section{CONCLUSIONS}

Using transglutaminase during cheese production can improve the yield, moisture content, protein content, other chemical compositions, and texture of the cheese. The results of this study should prove useful for the production of high-quality cheeses based on rheological and chemical parameters.

\section{ACKNOWLEDGEMENTS}

The authors thank Ira Novita Sari for writing guidance and the UAEU Editing Team for English language editing.

\section{AUTHORS' CONTRIBUTION}

All authors contributed equally to this work. All authors read and approved the final version of the manuscript.

\section{COMPETING INTERESTS}

There are no conflicts of interest to declare.

\section{REFERENCES}

Aaltonen T, Huumonen I, Myllärinen P. 2014. Controlled transglutaminase treatment in Edam cheese-making. Int Dairy J. 38(2):179-182. doi:10.1016/j.idairyj.2013.1 2.004.

Afandi F, Sulistyowati M, Wasito S. 2013. Pengaruh penambahan $\mathrm{CaCl}_{2}$ terhadap yield, kadar air, dan derajat keasaman keju susu kambing [Effect of addition of $\mathrm{CaCl}_{2}$ on yield, moisture content, and acidity of goat's milk cheese]. Jurnal Ilmiah Peternakan. 1(1):20-24.

Ahmed MKA, El-Nimer AMM, Mostafa M, Omar HH. 2016. Effect of fat replacer or transglutaminase on the quality of low-fat gouda-like cheese. World J Dairy Food Sci. 10(2):170-180.
Ali NA, Ahmed SH, Mohamed EA, Ahmed IAM, Babiker EE. 2010. Effect of transglutaminase cross linking on the functional properties as a function of Nacl concentration of legumes protein isolate. Int J Nutr Food Eng. 4(1):27-32. doi:10.5281/zenodo.1083231.

Budolfsen G, Nielsen P, inventors; Novo Nordisk AS, assignee. 1999 Feb 2. Method for production of an acidified edible gel on milk basis. United States patent US 5,866,180. https://patents.google.com/patent/US58 66180A.

Budtz P, inventor; Novo Nordisk AS, assignee. 2001 Jul 10. A process for making cheese. United States patent US 6,258,390. https://patents.google.com/patent/US62 $58390 \mathrm{~B} 1$.

Buettner K, Hertel TC, Pietzsch M. 2011. Increased thermostability of microbial transglutaminase by combination of several hot spots evolved by random and saturation mutagenesis. Amino Acids. 42(2-3):987-996. doi:10.1007/s00726-011-1015-y.

Bönisch MP, Heidebach TC, Kulozik U. 2008. Influence of transglutaminase protein cross-linking on the rennet coagulation of casein. Food Hydrocolloids. 22(2):288297. doi:10.1016/j.foodhyd.2006.11.015.

Bönisch MP, Huss M, Lauber S, Kulozik U. 2007. Yoghurt gel formation by means of enzymatic protein cross-linking during microbial fermentation. Food Hydrocolloids. 21(4):585-595. doi:10.1016/j.foodhyd.2006.07.002.

Campos N, Castañón S, Urreta I, Santos M, Torné J. 2013. Rice transglutaminase gene: identification, protein expression, functionality, light dependence and specific cell location. Plant Sci. 205-206:97-110. doi:10.1016/j.pl antsci.2013.01.014.

Chasanah E, Fawzya Y. 2014. Production and application of microbial transglutaminase to improve gelling capabilities of some Indonesian minced fish. In: Kim SK, editor. Seafood science. 1st edition. Boca Raton: CRC Press. p. 170-181. doi:10.1201/b17402.

Darnay L, Králik F, Oros G, Koncz Á, Firtha F. 2017. Monitoring the effect of transglutaminase in semi-hard cheese during ripening by hyperspectral imaging. J Food Eng. 196:123-129. doi:10.1016/j.jfoodeng.2016.10.020.

de Góes-Favoni SP, Bueno FR. 2014. Microbial transglu- 
taminase: general characteristics and performance in food processing technology. Food Biotechnol. 28(1):124. doi:10.1080/08905436.2013.870076.

Domagała J, Najgebauer-Lejko D, Wieteska-Śliwa I, Sady M, Wszołek M, Bonczar G, Filipczak-Fiutak M. 2015. Influence of milk protein cross-linking by transglutaminase on the rennet coagulation time and the gel properties. J Sci Food Agric. 96(10):3500-3507. doi:10.1002/jsfa.7 534.

Duarte L, Matte CR, Bizarro CV, Ayub MAZ. 2020. Transglutaminases: part I-origins, sources, and biotechnological characteristics. World J Microbiol Biotechnol. 36(1). doi:10.1007/s11274-019-2791-x.

Edam, Cheese and the City. 2005. The history of Edam cheese. Edam, Cheese and the City. [accessed $2021 \mathrm{Feb}$ 20]. http://www.edam.com/edam_cheese.htm.

Fawzya YN. 2016. Microbial transglutaminase of Indonesian Streptomyces sp.: screening and production in several media. Squalen Bull Mar Fish Postharvest Biotechnol. 11(1):13. doi:10.15578/squalen.v11i1.195.

Giosafatto C, Rigby N, Wellner N, Ridout M, Husband F, Mackie A. 2012. Microbial transglutaminase-mediated modification of ovalbumin. Food Hydrocolloids. 26(1):261-267. doi:10.1016/j.foodhyd.2011.06.003.

Grindstaff D, Chappell RA, inventors; Nutricepts Inc, assignee. 2006 Sep 19. Shaped cheese reconstruction with transglutaminase. United States patent US 7,108,876. https://patents.google.com/patent/US $7108876 \mathrm{~B} 2$.

Han XQ, Pfeifer JK, Lincourt RH, Schuerman JM, inventors; Kraft Foods Holdings Inc, assignee. 2003 Jun 3. Process for making a cheese product using transglutaminase. United States patent US 6,572,901. https://pate nts.google.com/patent/US6572901B2.

Han XQ, Spradlin JE, inventors; Kraft Foods Inc, assignee. $2000 \mathrm{Jul} 25$. Process for making cheese using transglutaminase and a non-rennet protease. United States patent US 6,093,424. https://patents.google.com/pat ent/US6093424A.

Han XQ, Spradlin JE, inventors; Kraft Foods Inc, assignee. 2001 May 1. Process for incorporating whey proteins into cheese using transglutaminase. United States patent US 6,224,914. https://patents.google.com/pat ent/US6224914B1.

Hinz K, Huppertz T, Kelly AL. 2012. Susceptibility of the individual caseins in reconstituted skim milk to crosslinking by transglutaminase: influence of temperature, pH and mineral equilibria. J Dairy Res. 79(4):414-421. doi: 10.1017/S0022029912000374.

Hoseyni Aghdam S, Dezyani M, Ezzaati R, Yasini Ardakani A, Daneshi M, Laripour Harat R, Bahadori Monfared A. 2013. The effect of microbial transglutaminase enzyme on textural and sensory properties of UF cheese. Iranian J Nutr Sci Food Technol. 7(5):481-487. http://nsft .sbmu.ac.ir/article-1-1042-en.html.

Hu Yn, Ge Ks, Jiang L, Guo Hy, Luo J, Wang F, Ren Fz. 2013. Effect of transglutaminase on yield, compositional and functional properties of low-fat Cheddar cheese. Food Sci Technol Res. 19(3):359-367. doi:10.3136/fstr.19.359.

Ibrahim OA, Nour MM, Khorshid MA, El-Hofi MA, ElTanboly ESE, Abd-Rabou NS. 2016. UF-white soft cheese cross-linked by rosemary transglutaminase. Int J Dairy Sci. 12(1):64-72. doi:10.3923/ijds.2017.64.72.

Jimenez CC. 2013. Increasing yield of panela type cheese like using a modified maize-soy protein and transglutaminase. J Food Process Technol. 4(10):87.

Kieliszek M, Misiewicz A. 2014. Microbial transglutaminase and its application in the food industry. A review. Folia Microbiol. 59(3):241-250. doi:10.1007/s12223-013-028 $7-\mathrm{x}$.

Kumazawa Y, Miwa N, inventors; Ajinomoto Co Inc, assignee. 2009 Mar 17. Process for producing cheese curd. United States patent US 7,504,119. https://patents.go ogle.com/patent/US7504119B2.

Kumazawa Y, Sakamoto J, Kuraishi C, Nio N, Sakaguchi S, inventors; Ajinomoto Co Inc, assignee. 2004 Jun 15. Cheese yield enhancing method. United States patent US 6,749,873. https://patents.google.com/patent/US 6749873B2.

Kuraishi C, Sakamoto J, Soeda T, inventors; Ajinomoto Co Inc, assignee. 1997 Oct 28. Process for producing cheese using transglutaminase. United States patent US 5,681,598. https://patents.google.com/patent/ US5681598A.

Kütemeyer C, Froeck M, Werlein HD, Watkinson B. 2005. The influence of salts and temperature on enzymatic activity of microbial transglutaminase. Food Control. 16(8):735-737. doi:10.1016/j.foodcont.2004.06.012.

Macedo JA. 2009. Produção, purificação, caracterização e aplicação de transglutaminase de Streptomyces sp. CBMAI 837 [Production, purification, characterization and application of transglutaminase from Streptomyces sp. CBMAI 837; dissertation]. [São Paulo]: Universidade Estadual de Campinas. http://repositorio.unicamp.br /jspui/handle/REPOSIP/254362.

Mahmood K, Nawal H, Ashna T. 2016. The effect of microbial transglutaminase enzyme on some physicochemical and sensory properties of goat's whey cheese. Int Food Res J. 32:688-693.

Mahmood WA. 2009. Effect of microbial transglutaminase treatment on soft cheese properties. Mesopotamia J Agric. 37(4):19-27. doi:10.33899/magrj.2009.27525.

Martins IM, Matos M, Costa R, Silva F, Pascoal A, Estevinho LM, Choupina AB. 2014. Transglutaminases: recent achievements and new sources. Appl Microbiol Biotechnol. 98(16):6957-6964. doi:10.1007/s00253-014 -5894-1.

Mazuknaite I, Guyot C, Leskauskaite D, Kulozik U. 2013. Influence of transglutaminase on the physical and chemical properties of acid milk gel and cottage type cheese. J Food Agric Env. 11:119-124.

Ministry of Trade of the Republic of Indonesia. 2019. Regulation of the Minister of Trade of the Republic of Indonesia number 29 of 2019 concerning provisions for import and export of animals and animal products. http: //jdih.kemendag.go.id/backendx/image/regulasi/ 09190701_Translate_29_Tahun_2019.pdf.

Miskiyah, Usmiati S, Mulyorini M. 2011. Pengaruh enzim proteolitik dengan bakteri asam laktat probiotik terhadap karakteristik dadih susu sapi [Effect of proteolytic enzymes of probiotic lactic acid bacteria on the characteristics of cow's milk curd]. Jurnal Ilmu Ternak dan Veteriner. 16(4):304-311.

Monogioudi E, Faccio G, Lille M, Poutanen K, Buchert J, Mattinen ML. 2011. Effect of enzymatic cross-linking of $\beta$ casein on proteolysis by pepsin. Food Hydrocolloids. 25(1):71-81. doi:10.1016/j.foodhyd.2010.05.007.

Motoki M, Seguro K. 1998. Transglutaminase and its use 
for food processing. Trends Food Sci Technol. 9(5):204210. doi:10.1016/S0924-2244(98)00038-7.

Muhammad AS, Abdulqader AA, AL-Ansi W, Sajid BM, AlJaberi H, Ejaz S, Habimana l, Hameed T, Xia L. 2021. Current industrial applications of microbial transglutaminase: a review. Int J Adv Eng Manage Sci. 7(3):81-92. doi:10.22161/ijaems.73.11.

Ojeda M, Etaio I, Valentin D, Dacremont C, Zannoni M, Tupasela T, Lilleberg L, Pérez-Elortondo FJ. 2021. Effect of consumers' origin on perceived sensory quality, liking and liking drivers: a cross-cultural study on European cheeses. Food Qual Preference. 87:104047. doi: 10.1016/j.foodqual.2020.104047.

Oliveira NM, Dourado FQ, Peres AM, Silva MV, Maia JM, Teixeira JA. 2011. Effect of guar gum on the physicochemical, thermal, rheological and textural properties of green Edam cheese. Food Bioprocess Technol. 4(8):1414-1421. doi:10.1007/s11947-010-0324-6.

Ouyang H, Kilcawley KN, Miao S, Fenelon M, Kelly A, Sheehan JJ. 2021. Exploring the potential of polysaccharides or plant proteins as structuring agents to design cheeses with sensory properties focused toward consumers in East and Southeast Asia: a review. Crit Rev Food Sci Nutr:1-14. doi:10.1080/10408398.2021.187486 9.

Ozcan T, Eren-Vapur U. 2013. Effect of different rennet type on physico-chemical properties and bitterness in white cheese. Int J Env Sci Dev:71-75. doi:10.7763/IJES D.2013.V4.307.

Pierro PD, Mariniello L, Sorrentino A, Giosafatto CVL, Chianese L, Porta R. 2010. Transglutaminase-induced chemical and rheological properties of cheese. Food Biotechnol. 24(2):107-120. doi:10.1080/089054310037 84465.

Prakasan V, Chawla SP, Sharma AR. 2015. Effect of transglutaminase treatment on functional properties of paneer. Int J Curr Microbiol Appl Sci. 4(5):227-238.

Rangkuti F, Wright T. 2015. Indonesia exporter guide. Global Agriculture Information Network report no. ID1548. Washington, DC: USDA Foreign Agricultural Service.

Romeih E, Walker G. 2017. Recent advances on microbial transglutaminase and dairy application. Trends Food Sci Technol. 62:133-140. doi:10.1016/j.tifs.2017.02.015.

Salinas-Valdés A, De la Rosa Millán J, Serna-Saldívar SO, Chuck-Hernández C. 2015. Yield and textural characteristics of Panela cheeses produced with dairy-vegetable protein (soybean or peanut) blends supplemented with transglutaminase. J Food Sci. 80(12):S2950-S2956. doi:10.1111/1750-3841.13126.

Sarghini F, Sorrentino A, Di Pierro P. 2013. An integrated mechanical-enzymatic reverse osmosis treatment of dairy industry wastewater and milk protein recovery as a fat replacer: a closed loop approach. J Agric Eng. 44(2s):283-286. doi:10.4081/jae.2013.299.
Sayadi A, Khosrowshahi AA, Madadlou A. 2012. The effect of transglutaminase on the chemical and textural characteristics and microstructure of low-fat white brined cheese. J Food Res. 22(1):19-19. https://www.sid.ir/e n/journal/ViewPaper.aspx?id=272484.

Sayadi A, Madadlou A, Khosrowshahi A. 2013. Enzymatic cross-linking of whey proteins in low fat Iranian white cheese. Int Dairy J. 29(2):88-92. doi:10.1016/j.idairyj.20 12.10.006.

Shi YG, Qian L, Zhang N, Han CR, Liu Y, Zhang YF, Ma YQ. 2011. Changes in morphology and activity of transglutaminase following cross-linking and immobilization on a polypropylene microporous membrane. Molecules. 16(12):10046-10058. doi:10.3390/molecu les161210046.

Shleikin AG, Danilov NP, Ternovskoy GV. 2011. Modification of food products properties by use of transglutaminase. Procedia Food Sci. 1:1568-1572. doi:10.1016/j.profoo.2 011.09.232.

Sidauruk SW, Nurhayati T, Suptijah P, Laksono UT. 2017. Karakterisasi enzim transglutaminase endogenous dari hati ikan cunang (Congresox talabon) [Characterization of endogenous transglutaminase enzymes from the liver of crayfish (Congresox talabon)]. Jurnal Pengolahan Hasil Perikanan Indonesia. 20(3):582-591.

Sorapukdee S, Tangwatcharin P. 2018. Quality of steak restructured from beef trimmings containing microbial transglutaminase and impacted by freezing and grading by fat level. Asian-Australasian J Anim Sci. 31(1):129137. doi:10.5713/ajas.17.0170.

United States Department of Agriculture. 2017. Safety of transglutaminase enzyme (TG enzyme). Washington, DC: United States Department of Agriculture; [accessed 2021 Feb 20]. https:/ / pregunteleakaren.gov/w $\mathrm{ps} /$ portal/fsis/topics/food-safety-education/getanswers/food-safety-fact-sheets/food-labeling/sa fety-of-transglutaminase-tg-enzyme.

United States Department of Agriculture Foreign Agricultural Service. 2019. Indonesia - food and agricultural import regulations and standards report. GAIN report no. 1841.

Yüksel Z, Avci E, Erdem YK. 2011. Modification of the renneting process in Berridge substrate by transglutaminase. Int J Dairy Technol. 64(3):365-371. doi:10.1111/j.1471-0 307.2011.00667.x.

Zilda DZ. 2014. Microbial transglutaminase: source, production and its role to improve surimi properties. Squalen Bull Mar Fish Postharvest Biotechnol. 9(1):35. doi:10.155 78/squalen.v9i1.82.

Özer B, Hayaloglu AA, Yaman H, Gürsoy A, Şener L. 2013. Simultaneous use of transglutaminase and rennet in white-brined cheese production. Int Dairy J. 33(2):129134. doi:10.1016/j.idairyj.2013.02.001. 